\title{
Modulation of NOX4 and MAPK Signalling Pathways by Parkia speciosa Empty Pods in H9c2 Cardiomyocytes Exposed to $\mathrm{H}_{2} \mathrm{O}_{2}$
}

\author{
J. S. GUI, N. H. MUSTAFA, J. JALIL ${ }^{1}$, Z. JUBRI ${ }^{2}$ AND Y. KAMISAH*
}

Department of Pharmacology, Faculty of Medicine, Universiti Kebangsaan Malaysia, 56000 Cheras, ${ }^{1}$ Drug and Herbal Research Centre, Faculty of Pharmacy, Universiti Kebangsaan Malaysia, 50300, ²Department of Biochemistry, Faculty of Medicine, Universiti Kebangsaan Malaysia, 56000 Cheras, Kuala Lumpur, Malaysia

\section{Gui et al.: Oxidative Stress Modulation by Parkia speciosa}

\begin{abstract}
Parkia speciosa, a plant that grows abundantly in Southeast Asia region, has been reported to exhibit antioxidant property. This study aimed to investigate the mechanism of antioxidant effects of empty pod extract of Parkia speciosa on hydrogen peroxide-induced oxidative stress in H9c2 cardiomyocytes. There were 4 groups of cardiomyocytes, the negative control, hydrogen peroxide, extract of Parkia speciosa+hydrogen peroxide and quercetin+hydrogen peroxide. Cardiomyocytes of groups 3 and 4 were preincubated for $1 \mathrm{~h}$ with $500 \mu \mathrm{g} / \mathrm{ml}$ of the ethyl acetate fraction of the Parkia speciosa extract or $1000 \mu \mathrm{M}$ quercetin prior to exposure to $500 \mu \mathrm{M}$ hydrogen peroxide for $1 \mathrm{~h}$. Hydrogen peroxide significantly increased the protein expression of NADPH oxidase 4, superoxide dismutase 1 and 338 mitogen-activated protein kinase, in comparison to the negative control. NADPH oxidase 4 and superoxide dismutase 1 activities as well as reactive oxygen species level were also elevated. These elevations were significantly decreased in the pretreated groups. The Parkia speciosa extract group had comparable effects to that of quercetin. Parkia speciosa extract showed antioxidant property against hydrogen peroxide-induced oxidative stress in H9c2 cardiomyocytes by regulating mitogen-activated protein kinase and NADPH oxidase 4 signalling pathways.
\end{abstract}

Key words: Petai, NADPH oxidase, MAPK, polyphenol, superoxide dismutase

Oxidative stress is involved in the development of diseases, which include cardiovascular diseases ${ }^{[1]}$. Increased oxidative stress in the cardiovascular system causes biochemical modification and oxidative injuries in the cells. There are many pathways involved in oxidative stress such as NADPH oxidase (NOX) pathways $^{[2]}$ and phospho-p38 mitogen-activated protein kinase (MAPK $)^{[3]}$. Activation of NOX4 would increase reactive oxygen species (ROS) generation, in particular superoxide anion $\left(\mathrm{O}_{2}^{-\bullet}\right)$, which then stimulates superoxide dismutase 1 (SOD1) to dismutase the anion ${ }^{[4,5]}$. ROS acts as a second messenger that stimulates MAPK activity ${ }^{[6]}$. Hydrogen peroxide $\left(\mathrm{H}_{2} \mathrm{O}_{2}\right)$ is one of the signaling molecules that can permeate the cell membrane and activate NOX. NOX4, but not NOX1 and NOX2 is upregulated in cardiac cells with increased oxidative stress ${ }^{[7]}$. Clinically, an increase in oxidative stress was reported in patients with ST-elevation myocardial infarction ${ }^{[8]}$.

Parkia speciosa Hassk, called as petai papan by the locals, of Leguminosae family, grows abundantly in
Southeast Asia region including Indonesia, Thailand, Philippines and Malaysia ${ }^{[9]}$. Its empty pods with or without seeds are used in folk medicine to help control heart problems ${ }^{[10]}$. The empty pods contain higher amounts of antioxidants than the seeds ${ }^{[11]}$, believed to be attributable to presence of quercetin, ellagic acid, gallic acid and catechin ${ }^{[12,13]}$. The pods were also reported to possess antiinflammatory property ${ }^{[13,14]}$.

The antioxidant property of $P$. speciosa extract (PSE) has been reported in many studies owing to the presence of polyphenols ${ }^{[15-17]}$. However, information on its antioxidant mechanism is still lacking. It might have a beneficial role in alleviating cardiovascular disease, thus, this study was conducted to further understand

This is an open access article distributed under the terms of the Creative Commons Attribution-NonCommercial-ShareAlike 3.0 License, which allows others to remix, tweak, and build upon the work non-commercially, as long as the author is credited and the new creations are licensed under the identical terms

Accepted 23 September 2019

Revised 21 June 2019

Received 02 March 2019

Indian J Pharm Sci 2019;81(6):1029-1035 
its antioxidant mechanism based on MAPK and NOX signaling pathways in $\mathrm{H} 9 \mathrm{c} 2$ cardiomyocytes that were induced by $\mathrm{H}_{2} \mathrm{O}_{2}$ as a model to enhance oxidative stress.

\section{MATERIALS AND METHODS}

\section{Preparation of PSE:}

Pods of $P$. speciosa plant were bought from a plantation in Bidor, Perak, Malaysia (Dec 2014). A voucher specimen (UKMB 40239) of the plant was located in the Universiti Kebangsaan Malaysia Herbarium (Bangi, Selangor, Malaysia) after its identification by a botanist. Preparation of ethyl acetate fraction from ethanol PSE was done according to a previously described method ${ }^{[13]}$. The fraction was then kept at $4^{\circ}$. The yield based on dry weight of the pods was $0.938 \%$.

\section{Phytochemical analysis of PSE:}

Phytochemical analysis of the PSE was conducted by the means of high-performance liquid chromatography (HPLC) according to a technique previously reported ${ }^{[18]}$ with some modifications ${ }^{[13]}$. The chromatographic system used was Waters 2535 with a photodiode array detector (Waters 2998, Waters Corp., Milford, MA, USA). A C-18 reversed-phased column was used $(5 \mu \mathrm{m}, 4.6 \times 250 \mathrm{~mm}$; XBridge, Waters, Dublin, Ireland). The system was set at $300 \mathrm{~nm}$. The mobile phases were $1 \%$ aqueous acetic acid solution (A) and acetonitrile (B), with the following gradient at ambient temperature, $13 \% \mathrm{~B}$ for the first $10 \mathrm{~min}$, then changed to $20 \%$ at $20 \mathrm{~min}, 30 \%$ at $30 \mathrm{~min}, 50 \%$ at $40 \mathrm{~min}$ and to $70 \%$ at $60 \mathrm{~min}$. At $80 \mathrm{~min}$, the gradient was reduced to $20 \% \mathrm{~B}$. The flow rate was $0.5 \mathrm{ml} / \mathrm{min}$. The obtained peaks were then compared against the retention time of catechin $(30.8 \mathrm{~min})$ and quercetin $(47.1 \mathrm{~min})$, the reference standards.

\section{Cell culture and treatment:}

H9c2 cardiomyocytes (ATCC, Manassas, Virginia, USA) were grown in Dulbecco's modified Eagle medium (DMEM) containing $1 \%$ penicillin/streptomycin/ amphotericin B solution (Gibco, Grand Island, NY, USA) and $10 \%$ fetal bovine serum (PAA Laboratories $\mathrm{GmbH}$, Pasching, Austria) in a humidified incubator (5\% $\mathrm{CO}_{2}$ and $95 \%$ air) at $37^{\circ}$. Cells at passages 4-7 were used in the study. There were 4 groups of cardiomyocytes, which were $\mathrm{H}_{2} \mathrm{O}_{2}(500 \mu \mathrm{M})$, PSE $\left(\begin{array}{llll}500 \mu \mathrm{g} / \mathrm{ml})+\mathrm{H}_{2} \mathrm{O}_{2} \quad(500 \mu & \mu \mathrm{M}\end{array}\right), \quad$ quercetin $(1000 \mu \mathrm{M})+\mathrm{H}_{2} \mathrm{O}_{2}(500 \mu \mathrm{M})$ serving as positive control $^{[19]}$ and a negative control $(0.1 \%$ dimethyl sulfoxide, DMSO in DMEM). The cells were pretreated for $1 \mathrm{~h}$ and exposure to $\mathrm{H}_{2} \mathrm{O}_{2}$ was for another $1 \mathrm{~h}$. The extract was dissolved in $0.1 \%$ DMSO which gave final concentration of $0.01 \%$ DMSO in the culture.

\section{Cell viability assay:}

Seeded cells $\left(3 \times 10^{4}\right.$ cells/well $)$ were used to measure the effects of various concentrations of $\mathrm{H}_{2} \mathrm{O}_{2}$ (50-550 $\mu \mathrm{M})$ on cell viability after $1 \mathrm{~h}$ using CellTiter 96 aqueous One Solution Proliferation Assay kit (Promega, Madison, Wisconsin, USA). The viability of the cells pretreated with various concentrations of the extract fraction $(31.25-1000 \mu \mathrm{g} / \mathrm{ml})$ for $1 \mathrm{~h}$, and then treated with median inhibitory concentration $\left(\mathrm{IC}_{50}\right)$ of $\mathrm{H}_{2} \mathrm{O}_{2}$ for another $1 \mathrm{~h}$, was also measured.

\section{Western blot analysis:}

The cells $\left(1.2 \times 10^{5}\right.$ cell $\left./ \mathrm{ml}\right)$ were seeded in T-75 flask. Extraction of protein samples from cultured cells and western blotting methods were according to previously described protocols ${ }^{[20,21]}$. The primary antibodies used were NOX4, $\beta$-actin (Santa Cruz Biotech, Dallas, Texas, USA), SOD1 and p38 MAPK with 1:100, 1:1000, 1:1000 and 1:500 dilutions, respectively. The secondary antibodies were goat antirabbit IgG-HRP (Cell Signaling, Danvers, Massachusetts, USA) or goat antimouse IgG-HRP (Santa Cruz Biotech, Dallas, Texas, USA) at 1:3000 dilution. The intensity of the oxidative stress related proteins were determined relatively to the intensity of the $\beta$-actin and all results were analysed using Image-J software.

\section{Preparation of cell lysate:}

The cells $\left(1.2 \times 10^{5}\right.$ cell $\left./ \mathrm{ml}\right)$ were seeded in $\mathrm{T}-75$ flask to obtain cell lysate. After being treated according to the groups, media in the culture flask were removed and the flask was rinsed with phosphate-buffered saline (PBS) solution twice. Then, the cells that attached to the surface of the flask were removed by using cell scraper. PBS solution containing the cells was centrifuged at $2500 \mathrm{rpm}$ for $5 \mathrm{~min}$. The cell pellet was resuspended in $1 \mathrm{ml}$ of PBS solution, before being centrifuged again at $2500 \mathrm{rpm}$ for $5 \mathrm{~min}$ at $4^{\circ}$. The resulting pellet was resuspended in $100 \mu \mathrm{l}$ of lysis buffer containing protease inhibitor (Complete Mini EDTA-free; Roche, Mannheim, Germany) and dithiothreitol $(0.154 \mathrm{mg} / \mathrm{ml})$ in radioimmunoprecipitation assay buffer (RIPA buffer 1x; Sigma-Aldrich, St. Louis, Missouri, USA). The tube was vortexed every $5 \mathrm{~min}$ thrice. Then, the tube was centrifuged at $12000 \mathrm{rpm}$ for $15 \mathrm{~min}$ at $4^{\circ}$. The resulting supernatant was the cell lysate. 


\section{Determination of NOX activity:}

NOX activity assay was carried out using cell lysate following an established method ${ }^{[22]}$. Briefly, $50 \mu \mathrm{g}$ cell lysate was added into a reaction mixture (final volume of $200 \mu \mathrm{l})$ that consisted of $250 \mu \mathrm{g} / \mathrm{l}$ cytochrome C (Sigma-Aldrich, St Louis, Minnesota, USA), $100 \mu \mathrm{M}$ NADPH (Sigma-Aldrich, St Louis, Minnesota USA), with or without $100 \mu \mathrm{M}$ diphenyleneiodonium chloride (Sigma-Aldrich, St Louis, Minnesota USA). The mixture was incubated for $120 \mathrm{~min}$ at $37^{\circ}$. Then, the absorbance was measured at $550 \mathrm{~nm}$ in ELISA microtiter plate reader. The difference between the sample absorbance values at 0 and $120 \mathrm{~min}$, was taken to calculate the NOX activity with the extinction coefficient $21 \mathrm{mmol} / \mathrm{l} / \mathrm{cm}$. It was expressed as percentage of control.

\section{Determination of intracellular ROS level:}

Cell-permeant fluorescent probe, 2',7'-dichloro dihydrofluorescein (DCFH-DA, Sigma-Aldrich, St Louis, Minnesota, USA) ${ }^{[23]}$ was used to determine ROS level in the cells $\left(5 \times 10^{4} \mathrm{cell} / \mathrm{ml}\right)$. The absorbance was read at $485 \mathrm{~nm}$ excitation and $535 \mathrm{~nm}$ emission by utilizing a fluorescence plate reader (EnSpire Multimode Plate Reader, PerkinElmer, USA). ROS level was expressed as percentage of control.

\section{Determination of SOD activity:}

SOD activity was determined ${ }^{[24-26]}$ in the cell lysate. Lysate mixed with $50 \mathrm{mM}$ PBS (pH 7.8), $201.06 \mathrm{mM}$ L-methionine (Sigma-Aldrich, St Louis, Minnesota, USA), $1.71 \mathrm{mM}$ nitro blue tetrazolium (Sigma-Aldrich, St Louis, Minnesota, USA), 1 \% Triton X-100 (SigmaAldrich, St Louis, Minnesota, USA) and $106.28 \mu \mathrm{M}$ riboflavin (Sigma-Aldrich, St Louis, Minnesota, USA) was placed in an illuminated aluminium box with two 20-watt Sylvania Arolux fluorescent lamps for $7 \mathrm{~min}$. The absorbance was read at $560 \mathrm{~nm}$ by a spectrophotometer (Shimadzu, Kyoto, Japan). SOD activity was calculated as $\%$ inhibition of blue formazan formed from the reaction of nitro blue tetrazolium and superoxide produced. The enzyme activity was depicted as $\mathrm{U} / \mathrm{mg}$ protein. The content of the protein was evaluated using Bradford reagent (Sigma-Aldrich, St Louis, Minnesota, USA).

\section{Statistical analysis:}

The experiments were conducted in triplicate. The data were expressed as mean \pm standard error of mean
(SEM). Shapiro-Wilk test was used to evaluate the normality of the data. For normally distributed data, one way analysis of variance (ANOVA) and Tukey's post-hoc test were applied, while for non-normally distributed data, Kruskal-Wallis test was conducted. $\mathrm{P}$ values $<0.05$ were considered statistically significant.

\section{RESULTS AND DISCUSSION}

$P$. speciosa empty pods has been reported to contain polyphenols ${ }^{[12,13]}$. In the present study, the PSE showed 5 main peaks in the chromatogram (fig. 1). However, only quercetin was detected in the extract. The quercetin content in the extract was about $5.74 \mathrm{mg}$ quercetin per $100 \mathrm{~g}$ dried extract. In our previous study, PSE ethyl acetate fraction contained the largest amount of quercetin compared to other fractions (ethanol and hexane $)^{[13]}$. Based on this, the ethyl acetate fraction was selected for further study and quercetin was chosen as the positive control.

H9c2 cardiomyocytes were cultured with increasing concentrations of $\mathrm{H}_{2} \mathrm{O}_{2}(50-550 \mu \mathrm{M})$ for $1 \mathrm{~h}$. The exposure to $\mathrm{H}_{2} \mathrm{O}_{2}$ had decreased $\mathrm{H} 9 \mathrm{c} 2$ cell viability concentration-dependently. The median inhibitory concentration $\left(\mathrm{IC}_{50}\right)$ value of $\mathrm{H}_{2} \mathrm{O}_{2}$ obtained was $500 \mu \mathrm{M}$ (fig. 2A). Pretreatment with PSE $(31.25 \mu \mathrm{g} / \mathrm{ml}$ to $1000 \mu \mathrm{g} / \mathrm{ml}$ ) prior to exposure to $500 \mu \mathrm{M} \mathrm{H}_{2} \mathrm{O}_{2}$ for $1 \mathrm{~h}$ had increased cell viability concentration-dependently compared to non-pretreated group $(0 \mu \mathrm{g} / \mathrm{ml})$ that was exposed to $\mathrm{H}_{2} \mathrm{O}_{2}(\mathrm{p}<0.05$, fig. $2 \mathrm{~B})$. The cell viabilities in groups pretreated with $31.25,62.5$ and $250 \mu \mathrm{g} / \mathrm{ml}$ PSE were not different. The group pretreated with $500 \mu \mathrm{g} / \mathrm{ml}$ PSE had the highest cell viability, which was $80.08 \pm 0.41 \%$, while in the group pretreated with $1000 \mu \mathrm{g} / \mathrm{ml}$ PSE was $72.14 \pm 0.64 \%$. The concentration of $500 \mu \mathrm{g} / \mathrm{ml}$ of PSE was selected to be used in subsequent experiments. The significant reduction in cell viability after $1 \mathrm{~h}$ exposure of $\mathrm{H}_{2} \mathrm{O}_{2}$ showed cytotoxic effect of $\mathrm{H}_{2} \mathrm{O}_{2}$. The $\mathrm{IC}_{50}$ of $\mathrm{H}_{2} \mathrm{O}_{2}$ obtained in the present study was similarly reported ${ }^{[27]}$. The peroxide produces hydroxyl radicals in the presence on ferric ion, and superoxide anion which are toxic to cells and increases oxidative stress ${ }^{[28]}$, leading to cell death. The protective effects of PSE against cell death induced by $\mathrm{H}_{2} \mathrm{O}_{2}$ most probably owing to high content of flavonoid and phenolic compounds present in the empty pods ${ }^{[15]}$.

$\mathrm{H} 9 \mathrm{c} 2$ cells exposed to $\mathrm{H}_{2} \mathrm{O}_{2}$ have been used as a model for evaluating the effects of natural compounds on cardiovascular diseases that are caused by oxidative 

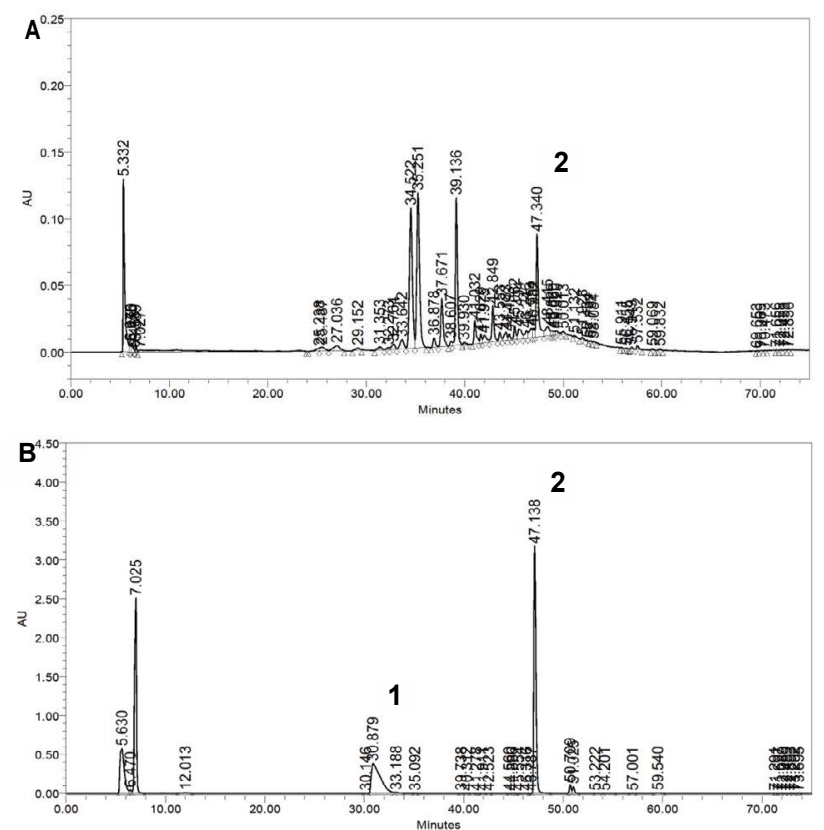

Fig. 1: Chromatography analysis

(A) Parkia speciosa extract (peak 2- quercetin) based on (B) reference standards (peak 1- catechin at 30.8 min and peak 2quercetin at $47.1 \mathrm{~min}$ ) detected at $300 \mathrm{~nm}$

stress $^{[5,25]}$. Oxidative stress enhances ROS production and increases the risk for cardiovascular disease ${ }^{[26]}$. Overproduction of ROS is believed to contribute to the declining cardiac function in patients with cardiac disease $^{[8]}$. It is known that NOX is involved in one of the pathways in oxidative stress. Induction with $\mathrm{H}_{2} \mathrm{O}_{2}$ elevated the NOX4 protein expression significantly $(1.17 \pm 0.02, \mathrm{p}<0.05)$ compared to the negative control. PSE and quercetin pretreatments significantly blocked the elevation of the NOX4 induced by $\mathrm{H}_{2} \mathrm{O}_{2}$. In the negative control, $\mathrm{PSE}+\mathrm{H}_{2} \mathrm{O}_{2}$ and quercetin $+\mathrm{H}_{2} \mathrm{O}_{2}$ groups, there was no detectable NOX4 expression was observed (fig. 3A). NOX activity was significantly more than two-fold higher $(383.33 \pm 16.67 \%, \mathrm{p}<0.05)$ in $\mathrm{H} 9 \mathrm{c} 2$ cells that were exposed to $\mathrm{H}_{2} \mathrm{O}_{2}$ than the negative control. PSE $(183.33 \pm 16.67 \%)$ and quercetin $(150.00 \pm 28.87 \%)$ pretreatments had reduced NOX activity significantly compared to $\mathrm{H}_{2} \mathrm{O}_{2}$ group $(\mathrm{p}<0.05)$. NOX activity was similar in both pretreated groups, which was also comparable to the negative control (fig. 3B). The ROS level was measured to confirm the presence of oxidative stress. Exposure to $\mathrm{H}_{2} \mathrm{O}_{2}$ significantly augmented intracellular ROS level $(163.76 \pm 4.23 \%)$ in H9c2 cells. Both PSE (92.85 \pm $0.98 \%)$ and quercetin $(94.34 \pm 2.87 \%)$ groups that were treated with $\mathrm{H}_{2} \mathrm{O}_{2}$ had significantly lower intracellular ROS level than the negative control and $\mathrm{H}_{2} \mathrm{O}_{2}$ groups. In the pretreated groups, the ROS levels were similar (fig. 4).
Elevation of oxidative stress induced by $\mathrm{H}_{2} \mathrm{O}_{2}$ promotes NOX4 expression, and then its activity as seen in this study. NOX4 is the main isoform of NOX expressed in the cardiomyocytes and the major source of $\mathrm{O}_{2}{ }^{-}$ in the heart ${ }^{[29,30]}$. Its activation involves $\mathrm{p} 22^{\text {phox }}$ and polymerase delta interacting protein 2 (Poldip2) ${ }^{[31]}$. When induced with $\mathrm{H}_{2} \mathrm{O}_{2}, \mathrm{p} 22^{\text {phox }}$ forms a stabilizing complex with $\mathrm{NOX} 4$, followed by the translocation of Poldip2 to form an active complex ${ }^{[31,32]}$. Then, NOX4 produces $\mathrm{O}_{2}{ }^{-}$by transferring electrons from NADPH to

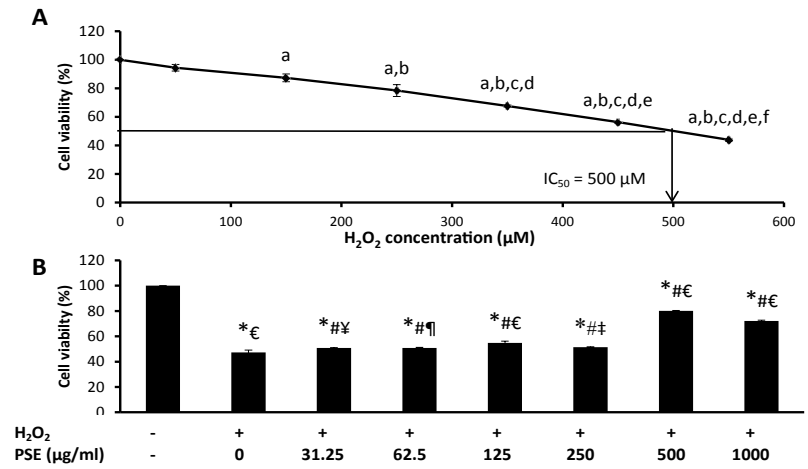

Fig. 2: Cell viabilities in $\mathrm{H9c2}$ cardiomyocytes

(A) treated with various concentrations of $\mathrm{H}_{2} \mathrm{O}_{2}$ for $1 \mathrm{~h}$ and (B) pretreated with various concentrations of Parkia speciosa extract (PSE) for $1 \mathrm{~h}$, followed by $1 \mathrm{~h}$ incubation with $\mathrm{H}_{2} \mathrm{O}_{2}$ $(500 \mu M)$. Data are shown as mean \pm SEM $(n=3)$. a $p<0.05$ vs. $0 \mu \mathrm{M},{ }^{\mathrm{b}} \mathbf{p}<0.05$ vs. $50 \mu \mathrm{M},{ }^{\mathrm{c}} \mathrm{p}<0.05$ vs. $150 \mu \mathrm{M},{ }^{\mathrm{d}} \mathbf{p}<0.05$ vs. 250 $\mu M,{ }^{\mathrm{e}} \mathbf{p}<0.05$ vs. $350 \mu \mathrm{M},{ }^{\mathrm{f}} \mathbf{p}<0.05$ vs. $450 \mu \mathrm{M} .{ }^{*} \mathbf{p}<0.05$ vs. negative control, ${ }^{\#} \mathbf{p}<0.05$ vs. $\mathrm{H}_{2} \mathrm{O}_{2},{ }^{\epsilon} \mathbf{p}<0.05$ vs. other PSE concentrations, ${ }^{q} \mathbf{p}<0.05$ vs. other PSE concentrations except $62.5 \mu \mathrm{g} / \mathrm{ml}$ and $250 \mu \mathrm{g} / \mathrm{ml},{ }^{\mathrm{q}} \mathrm{p}<0.05$ vs. other PSE concentrations except $31.25 \mu \mathrm{g} / \mathrm{ml}$ and $250 \mu \mathrm{g} / \mathrm{ml},{ }^{\ddagger} \mathrm{p}<0.05$ vs. other PSE concentrations except $31.25 \mu \mathrm{g} / \mathrm{ml}$ and $62.5 \mu \mathrm{g} / \mathrm{ml}$

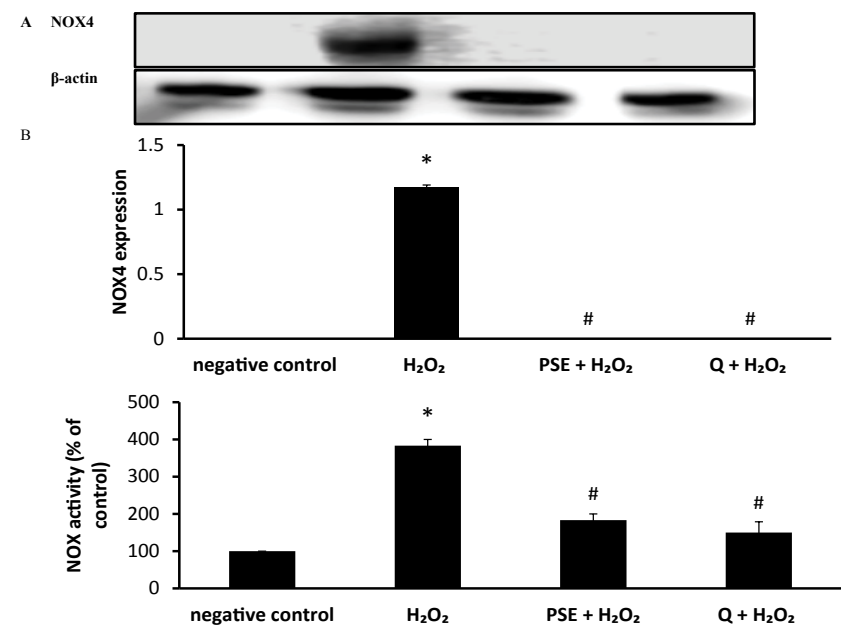

Fig. 3: Pretreatment with PSE and quercetin on NADPH oxidase in $\mathrm{H} 9 \mathrm{c} 2$ cardiomyocytes exposed to $\mathrm{H}_{2} \mathrm{O}_{2}$

Effect of pretreatment with $500 \mu \mathrm{g} / \mathrm{ml}$ Parkia speciosa extract (PSE) and $1000 \mu M$ quercetin (Q) on (A) NADPH oxidase (NOX) expression and (B) NOX activity in $\mathrm{H} 9 \mathrm{c} 2$ cardiomyocytes exposed to $500 \mu \mathrm{M}$ of $\mathrm{H}_{2} \mathrm{O}_{2}$. Data shown as mean \pm SEM $(n=3)$. ${ }^{*} \mathbf{p}<\mathbf{0 . 0 5}$ vs. negative control, ${ }^{*} \mathbf{p}<0.05$ vs. $\mathrm{H}_{2} \mathrm{O}_{2}$ 


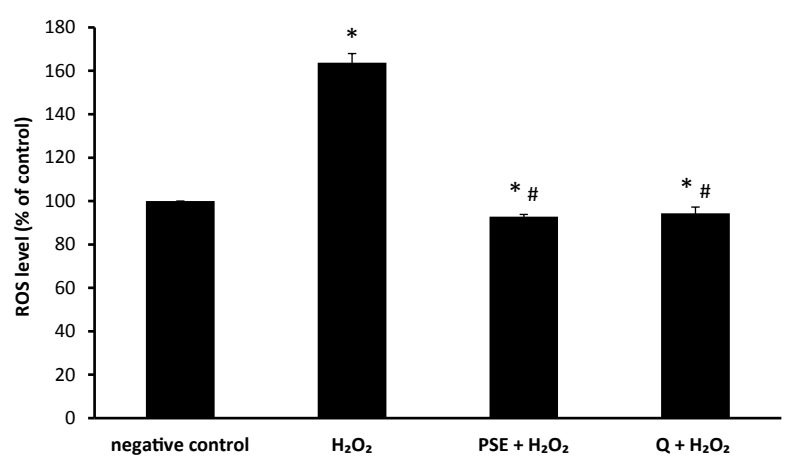

Fig. 4: ROS level in $\mathrm{H9c2}$ cardiomyocytes pretreated with $500 \mu \mathrm{g} / \mathrm{ml}$ PSE and Q prior to exposure to $\mathrm{H}_{2} \mathrm{O}_{2}$ Reactive oxygen species (ROS) level in $\mathrm{H9c2}$ cardiomyocytes pretreated with $500 \mu \mathrm{g} / \mathrm{ml}$ Parkia speciosa extract (PSE) and $1000 \mu M$ quercetin $(Q)$ prior to exposure to $500 \mu M$ of $\mathrm{H}_{2} \mathrm{O}_{2}$. Data shown as mean \pm SEM $(n=3)$. ${ }^{*} p<0.05$ vs. negative control, ${ }^{\#} \mathbf{p}<0.05$ vs. $\mathrm{H}_{2} \mathrm{O}_{2}$

$\mathrm{O}_{2}$ and $\mathrm{O}_{2} \cdot{ }^{-[33]}$. The effect of $\mathrm{H}_{2} \mathrm{O}_{2}$ on $\mathrm{NOX} 4$ expression was totally blocked by the PSE and quercetin. It was similarly demonstrated ${ }^{[34]}$ that showed reduction of NOX4 expression by ZYZ-772, a quercetin metabolite from Zanthoxylum bungeanum in H9c2 cells. On the other hand, the NOX activity was not similarly blocked in both groups (PSE and quercetin) because the activity measured was not NOX4-specific, but measured total activity of other NOXs as well (NOX1, NOX2, NOX3, NOX5, DUOX1 and DUOX2). The protective effect of PSE was most likely afforded by its quercetin content. It is postulated that PSE and quercetin inhibited Poldip2 translocation to $\mathrm{p} 22^{\text {phox }}$ in the membrane, as well as inhibited translocation of cytosolic subunit ( $\mathrm{p} 40^{\text {phox }}$, $\mathrm{p} 47^{\text {phox }}$ and $\left.\mathrm{p} 67^{\text {phox }}\right)$ to the membrane and hence, the formation of active oxidase to form $\mathrm{O}_{2}{ }^{\cdot[35]}$.

In $\mathrm{H}_{2} \mathrm{O}_{2}$-treated $\mathrm{H} 9 \mathrm{c} 2$ cells, SOD1 protein expression was significantly increased $(1.34 \pm 0.08, \quad \mathrm{p}<0.05)$. The increment was significantly attenuated in the groups pretreated with PSE $(0.82 \pm 0.07)$ and quercetin $(0.20 \pm 0.08, \quad \mathrm{p}<0.05)$. Quercetin pretreatment had significantly diminished SOD1 protein expression, which expression was significantly smaller than the negative control group and PSE-pretreated group $(\mathrm{p}<0.05)$. The protein expression observed between the negative control group and PSE-pretreated group was not different (fig. 5A). Incubation with $\mathrm{H}_{2} \mathrm{O}_{2}$ significantly elevated SOD activity $(127.01 \pm 10.73$ $\mathrm{U} / \mathrm{mg}$ protein) in the cells compared to the negative control $(81.97 \pm 5.60 \mathrm{U} / \mathrm{mg}$ protein). The SOD activity was decreased to $69.86 \pm 6.87 \mathrm{U} / \mathrm{mg}$ protein in the PSE-pretreated and $49.46 \pm 5.78 \mathrm{U} / \mathrm{mg}$ protein in the quercetin-pretreated groups, compared to the $\mathrm{H}_{2} \mathrm{O}_{2}$ group $(\mathrm{p}<0.05)$. The activity of the enzyme was not different in both pretreated groups, and comparable to the activity of the negative control group (fig. 5B).

Upregulation of NOX4 and elevated NOX activity in the present study increased production of ROS in the cells, which was mitigated by PSE and quercetin. $\mathrm{O}_{2}{ }^{-}$ is importantly involved in the pathogenesis of many diseases, like hypertension and atherosclerosis ${ }^{[36]}$. Quercetin in the PSE might be neutralizing ROS by donating electrons or hydrogen atoms. Produced $\mathrm{O}_{2}{ }^{-}$is subsequently converted to $\mathrm{H}_{2} \mathrm{O}_{2}$ by $\mathrm{SOD}^{[33]}$. Therefore, increased production of the anion following exposure to $\mathrm{H}_{2} \mathrm{O}_{2}$ had increased the expression and activity of the SOD1, as observed in the present study, in turn to increase the synthesis of functional SOD enzyme to convert $\mathrm{O}_{2}{ }^{--}$anion to less reactive $\mathrm{H}_{2} \mathrm{O}_{2}{ }^{[4]}$, which is then converted into water and oxygen by catalase and glutathione peroxidase ${ }^{[37]}$. SOD is the primary defense mechanism and plays more important role in detoxifying ROS than catalase and glutathione peroxidase $^{[4]}$.

Reduced formation of ROS by both PSE and quercetin had reduced the demand to increase SOD1 synthesis in the cells, as proven by decreased expression and activity of the antioxidant enzyme. Quercetin had stronger effect on SOD1 downregulation than PSE, possibly attributable to its higher concentration $(1000 \mu \mathrm{M})$ than in the latter $(2.12 \mu \mathrm{M})$. However, its effect on the SOD activity was comparable with PSE, which might be due to the post-translational modification that leads to decreased SOD enzyme synthesis by the quercetin.

p38 MAPK is one of the pathways known to be involved in oxidative stress. Therefore, the protein expression of MAPK was determined to confirm the involvement of the kinase in the protective effect of PSE. $\mathrm{H}_{2} \mathrm{O}_{2}$ induction in $\mathrm{H} 9 \mathrm{c} 2$ cells significantly $(\mathrm{p}<0.05)$ increased $\mathrm{p} 38$ MAPK protein expression in comparison to the negative control group (fig. 6). p38 MAPK protein expression was significantly reduced in with PSE- $(0.07 \pm 0.02)$ and quercetin-pretreated groups compared to the $\mathrm{H}_{2} \mathrm{O}_{2}$ group $(\mathrm{p}<0.05)$. PSE-pretreated group had significantly greater p38 MAPK protein expression than the negative control. Quercetinpretreated group had comparable protein expression with the negative control group and significantly lower protein expression than PSE-pretreated group. No p38 MAPK expression was detected in the quercetinpretreated and negative control groups. 
www.ijpsonline.com
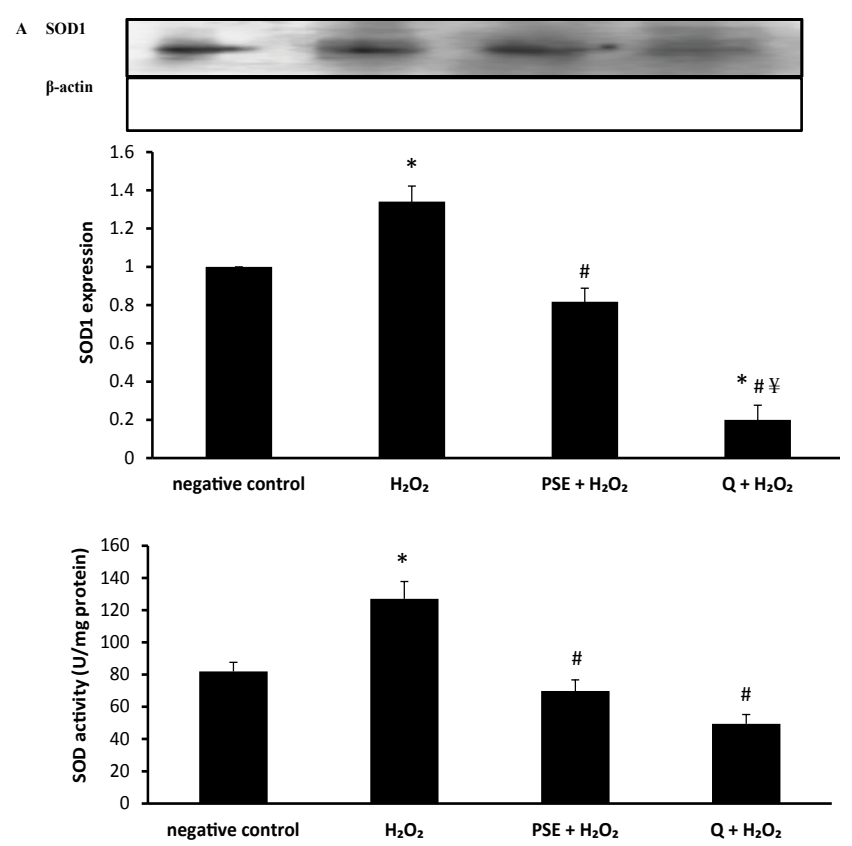

Fig. 5: Expression of SOD1 in H9c2 cardiomyocytes pretreated with PSE and quercetin prior to exposure to $\mathrm{H}_{2} \mathrm{O}_{2}$

The relative expression level of SOD1 (A) and activity (B) in H9c2 cardiomyocytes pretreated with $500 \mu \mathrm{g} / \mathrm{ml}$ Parkia speciosa extract (PSE) and $1000 \mu \mathrm{M}$ quercetin (Q) followed by $\mathrm{H}_{2} \mathrm{O}_{2}$ exposure. Data shown as mean \pm SEM $(n=3)$. ${ }^{*} p<0.05$ vs. negative control, ${ }^{\#} p<0.05$ vs. $\mathrm{H}_{2} \mathrm{O}_{2},{ }^{\mathrm{v}} \mathbf{p}<0.05$ vs. $\mathrm{PSE}+\mathrm{H}_{2} \mathrm{O}_{2}$
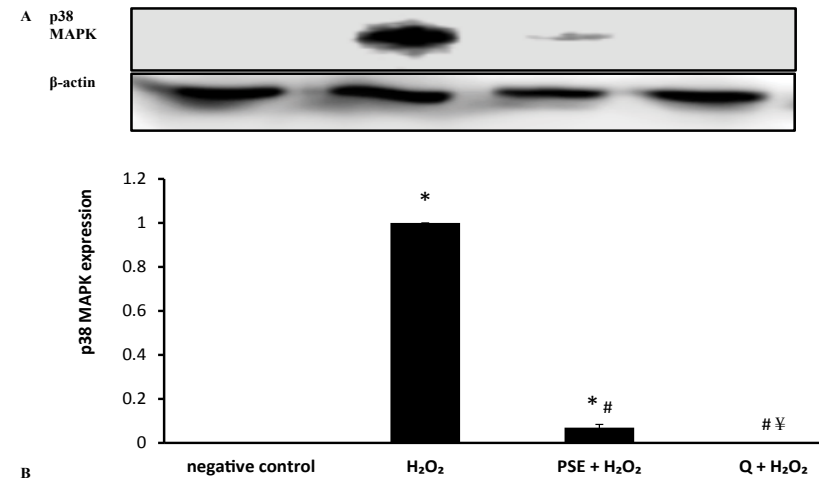

Fig. 6: Expression of p38 MAPK in H9c2 cells treated with PSE quercetin before exposure to $\mathrm{H}_{2} \mathrm{O}_{2}$

The relative expression level of $\mathrm{p38}$ MAPK in $\mathrm{H} 9 \mathrm{c} 2$ cells treated with $500 \mu \mathrm{g} / \mathrm{ml}$ Parkia speciosa extract (PSE) and $1000 \mu \mathrm{M}$ quercetin (Q) for $1 \mathrm{~h}$ before exposure to $500 \mu \mathrm{M}$ of $\mathrm{H}_{2} \mathrm{O}_{2}$ for $1 \mathrm{~h}$. Data shown as mean $\pm \operatorname{SEM}(n=3) .{ }^{*} p<0.05$ vs. the negative control, ${ }^{\#} \mathbf{p}<0.05$ vs. $\mathrm{H}_{2} \mathrm{O}_{2},{ }^{y} \mathbf{p}<0.05$ vs. $\mathrm{PSE}+\mathrm{H}_{2} \mathrm{O}_{2}$

ROS triggers phosphorylation and activation of $\mathrm{p} 38$ MAPK, evidenced by augmented expression of the kinase and such effect was attenuated by PSE and quercetin. $\mathrm{H}_{2} \mathrm{O}_{2}$ might cause oxidative modification of the intracellular kinase (MAP kinase kinase kinase, MAP3Ks), which is involved in the first step for p38 MAPK activation ${ }^{[38]}$, or deactivation of MAPK phosphatases (MKPs) ${ }^{[19]}$. Few other studies had previously shown that elevated ROS produced by
$\mathrm{H}_{2} \mathrm{O}_{2}$ activated p38 MAPK phosphorylation ${ }^{[6,34]}$. PSE and quercetin could be triggering MKPs deactivation of MAPK by dephosphorylating residues of tyrosine and threonine at the MAPK activation site ${ }^{[39]}$. More prominent inhibitory effect of quercetin on p38 MAPK expression could be due to its higher concentration.

The current in vitro study indicated the protective effects of PSE in impeding oxidative stress-associated cardiovascular diseases. It's in vitro beneficial effects needs to be further confirmed by in vivo studies, before its use as a supplement to reduce the risk of cardiovascular diseases. In conclusion, the current findings suggested that PSE acted as an antioxidant and protected $\mathrm{H} 9 \mathrm{c} 2$ cardiomyocytes against $\mathrm{H}_{2} \mathrm{O}_{2}$-induced oxidative stress by modifying NOX4 and MAPK signalling pathways. Its effects were comparable to that of quercetin, but less effective in downregulating SOD1 and p38 MAPK. The beneficial effects of this plant could be most probably owing to the polyphenol content, particularly quercetin.

\section{Acknowledgments:}

The authors thanked technical aid provided by Encik Fadhlullah Zuhair Japar Sidik, Puan Juliana Abdul Hamid and Puan Nurul Hafizah Abas. This work was financially supported by Universiti Kebangsaan Malaysia (AP-2014-013).

\section{REFERENCES}

1. Siti HN, Kamisah Y, Kamsiah J. The role of oxidative stress, antioxidants and vascular inflammation in cardiovascular disease (a review). Vascul Pharmacol 2015;71:40-56.

2. Cao YJ, Zhang YM, Qi JP, Liu R, Zhang H, He LC. Ferulic acid inhibits $\mathrm{H}_{2} \mathrm{O}_{2}$-induced oxidative stress and inflammation in rat vascular smooth muscle cells via inhibition of the NADPH oxidase and NF- $\mathrm{BB}$ pathway. Int Immunopharmacol 2015;28:1018-25.

3. Evans JL, Goldfine ID, Maddux BA, Grodsky GM. Oxidative stress and stress-activated signaling pathways: a unifying hypothesis of type 2 diabetes. Endocr Rev 2002;23:599-622.

4. Dhawan V. Reactive oxygen and nitrogen species: General considerations. In: Saha GK, Jindal SK, Biswal S, Barnes PJ, Pawankar R, editors. Studies on Respiratory Disorders. New York: Humana Press; 2014. p. 27-47.

5. Zhang F, Huang B, Zhao Y, Tang S, Xu H, Wang L, et al. BNC protects $\mathrm{H} 9 \mathrm{c} 2$ cardiomyoblasts from $\mathrm{H}_{2} \mathrm{O}_{2}$-induced oxidative injury through ERK1/2 signaling pathway. Evid Based Complement Altern Med 2013;2013:1-12.

6. Daubney J, Bonner PL, Hargreaves AJ, Dickenson JM. Cardioprotective and cardiotoxic effects of quercetin and two of its in vivo metabolites on differentiated H9c2 cardiomyocytes. Basic Clin Pharmacol Toxicol 2015;116:96109.

7. Varga ZV, Kupai K, Szücs G, Gáspár R, Pálóczi J, Faragó $\mathrm{N}$, et al. MicroRNA-25-dependent up-regulation of NADPH 
oxidase 4 (NOX4) mediates hypercholesterolemia-induced oxidative/nitrative stress and subsequent dysfunction in the heart. J Mol Cell Cardiol 2013;62:111-21.

8. Ekeløf S, Jensen SE, Rosenberg J, Gögenur I. Reduced oxidative stress in STEMI patients treated by primary percutaneous coronary intervention and with antioxidant therapy: A systematic review. Cardiovasc Drugs Ther 2014;28:173-81.

9. Balaji K, Nedumaran SA, Devi T, Sikarwar MS, Fuloria S. Phytochemical analysis and in vitro antioxidant activity of Parkia speciosa. Int J Green Pharm 2015;9:S50-4.

10. Yullia T. Prakata. In: Petai VM, Jengkol, editors. Tim Dapur DeMedia, DeMedia Pustaka. 1st ed. Indonesia: Jakarta Selatan; 2008. p. 2.

11. Kamisah Y, Othman F, Qodriyah HMS, Jaarin K. Parkia speciosa Hassk: A potential phytomedicine. Evid Based Complement Altern Med 2013;2013:1-9.

12. Ko HJ, Ang LH, Ng LT. Antioxidant activities and polyphenolic constituents of bitter bean Parkia speciosa. Int J Food Prop 2014;17:1977-86.

13. Mustafa NH, Ugusman A, Jalil J, Kamisah Y. Antiinflammatory properties of Parkia speciosa empty pod extract in human umbilical vein endothelial cells. J Appl Pharm Sci 2018;8:152-8.

14. Gui JS, Jalil J, Jubri Z, Kamisah Y. Parkia speciosa empty pod extract exerts anti-inflammatory properties by modulating $\mathrm{NF \kappa B}$ and MAPK pathways in cardiomyocytes exposed to tumor necrosis factor- $\alpha$. Cytotechnology 2019;71:79-89.

15. Kamisah Y, Zuhair JSF, Juliana AH, Jaarin K. Parkia speciosa empty pod prevents hypertension and cardiac damage in rats given $\mathrm{N}(\mathrm{G})$-nitro-l-arginine methyl ester. Biomed Pharmacother 2017;96:291-8.

16. Reihani SFS, Azhar ME. Antioxidant activity and total phenolic content in aqueous extracts of selected traditional Malay salads (Ulam). Int Food Res J 2012;19:1439-44.

17. Tunsaringkarn T, Soogarun S, Rungsiyothin A, Palasuwan A. Inhibitory activity of Heinz body induction in vitro antioxidant model and tannin concentration of Thai mimosaceous plant extracts. J Med Plant Res 2012;6:4096-101.

18. Komolafe K, Olaleye TM, Omotuyi OI, Boligon AA, Athayde ML, Akindahunsi AA, et al. In vitro antioxidant activity and effect of Parkia biglobosa bark extract on mitochondrial redox status. J Acupunct Meridian Stud 2014;7:202-10.

19. Chen YW, Chou HC, Lin ST, Chen YH, Chang YJ, Chen L, et al. Cardioprotective effects of quercetin in cardiomyocyte under ischemia/reperfusion injury. Evid Based Complement Altern Med 2013;2013:1-16.

20. Mahmood T, Yang PC. Western blot: technique, theory and troubleshooting. N Am J Med Sci 2012;4:429-34.

21. Sambrook J, Fritsch EF, Maniatis T. Molecular cloning: A laboratory manual. Vol 3. 3rd ed. New York: Cold Spring Harbor Laboratory Inc.; 2001.

22. Mustapha NM, Tarr JM, Kohner EM, Chibber R. NADPH oxidase versus mitochondria-derived ROS in glucose- induced apoptosis of pericytes in early diabetic retinopathy. J Ophthalmol 2010;2010:1-10.

23. Yang Y, Kim SC, Yu T, Yi YS, Rhee MH, Sung GH, et al. Functional roles of p38 mitogen-activated protein kinase in macrophage-mediated inflammatory responses. Mediators Inflamm 2014;2014:1-13.

24. Beyer WF, Fridovich I. Assaying for superoxide dismutase activity: some large consequences of minor changes in conditions. Anal Biochem 1987;161:559-66.

25. Mojarrab M, Jamshidi M, Ahmadi F, Alizadeh E, Hosseinzadeh L. Extracts of Artemisia ciniformis protect cytotoxicity induced by hydrogen peroxide in $\mathrm{H} 9 \mathrm{c} 2$ cardiac muscle cells through the inhibition of reactive oxygen species. Adv Pharmacol Sci 2013;2013:1-5.

26. Dhalla NS, Temsah RM, Netticadan T. Role of oxidative stress in cardiovascular diseases. J Hypertens 2000;18:655-73.

27. Ariumi H, Aso K, Yoshiyama Y. Hydrogen gas protects H9c2 cardiomyocytes from $\mathrm{H}_{2} \mathrm{O}_{2}$-induced oxidative stress. AATEX 2014;19:51-4.

28. Imlay JA. Cellular defenses against superoxide and hydrogen peroxide. Annu Rev Biochem 2008;77:755-76.

29. Ago T, Matsushima S, Kuroda J, Zablocki D, Kitazono T, Sadoshima J. The NADPH oxidase Nox4 and aging in the heart. Aging 2010;2:1012-6.

30. Kuroda J, Ago T, Matsushima S, Zhai P, Schneider MD, Sadoshima J. NADPH oxidase 4 (Nox4) is a major source of oxidative stress in the failing heart. Proc Natl Acad Sci U S A 2010;107:15565-70.

31. Miller FJ Jr. Nox4-walking the walk with Poldip2. Circ Res 2009;105:209-10.

32. Bedard K, Krause KH. The NOX family of ROS-generating NADPH oxidases: physiology and pathophysiology. Physiol Rev 2007;87:245-313.

33. Brown DI, Griendling KK. Nox proteins in signal transduction. Free Radic Biol Med 2009;47:1239-53.

34. Wang Y, Zhong L, Liu X. ZYZ-772 prevents cardiomyocyte injury by suppressing Nox4-derived ROS production and apoptosis. Molecules 2017;22:E331.

35. Maraldi T. Natural compounds as modulators of NADPH oxidases. Oxid Med Cell Longev 2013;2013:1-10.

36. Fukai T, Ushio-Fukai M. Superoxide dismutases: role in redox signaling, vascular function, and diseases. Antioxid Redox Signal 2011;15:1583-606.

37. Paravicini TM, Touyz RM. NADPH oxidases, reactive oxygen species, and hypertension: clinical implications and therapeutic possibilities. Diab Care 2008;31:S170-80.

38. Son Y, Cheong YK, Kim NH, Chung HT, Kang DG, Pae H. Mitogen-activated protein kinases and reactive oxygen species: how can ROS activate MAPK pathways? J Signal Transduct 2011;2011:792639.

39. Kondoh K, Nishida E. Regulation of MAP kinases by MAP kinase phosphatases. Biochim Biophys Acta 2007;1773:122737. 